\title{
MEKANISME PENYELESAIAN SENGKETA GATT DAN WTO DITINJAU DARI SEGI HUKUM PENYELESAIAN SENGKETA INTERNASIONAL
}

\author{
Oleh : \\ Lona Puspita, SH.MH \\ Dosen Fakultas Hukum Universitas Tamansiswa Padang
}

\begin{abstract}
Abstrack
The development of science and technology and the pattern of community activities in the world increasingly touch each other, need each other and determine each other destiny, but also compete with each other, especially in trade. With the establishment of an international trade organization or WTO increasingly eliminates the boundaries between countries. Therefore many cause problems in the implementation of inter-state trade agreements. This research uses normative legal research with primary data source that is secondary data. The research finds that international dispute resolution mechanism is one of the mechanisms of supervision in international law. While the relation between GATT and WTO dispute settlement method with international dispute settlement that is both can be done judicially and non-judicially.
\end{abstract}

\section{Latar Belakang Masalah}

Perkembangan ilmu pengetahuan dan teknologi serta pola kegiatan masyarakat di dunia semakin saling bersentuhan, saling membutuhkan dan saling menentukan nasib satu sama lain, tetapi juga saling bersaing. Hal ini secara dramatis terutama terlihat dalam kegiatan perdagangan dunia, baik barang maupun jasa. Saling keterkaitan ini memerlukan adanya kesepakatan mengenai aturan main yang berlaku. Aturan main yang diterapkan untuk perdagangan internasional adalah aturan main yang berkembang dalam sistem GATT dan WTO.

Sistem perdagangan internasional yang kini berlaku dan yang sekarang dikelola oleh suatu lembaga internasional baru, Wold Trade Organization atau selanjutnya disingkat WTO, mempunyai sejarah yang cukup panjang. Sebagai sistem yang menyeluruh, aturan main dalam WTO tidak dapat mudah dimengerti tanpa menoleh 
lebih jauh pada dasar-dasar yag telah diterapkan sejak didirikannya General Agreement on Tariff and Trade atau selajutnya disingkat GATT pada tahun $1947 .{ }^{1}$ GATT adalah suatu sistem, suatu forum dan suatu lembaga internasional dibidang perdagangan. ${ }^{2}$ Sistem tersebut mulai diwujudkan tahun 1947 dan mulai beroperasi tahun 1948.

GATT berfungsi sebagai suatu kontrak antara semua pihak peserta perjanjian untuk memenuhi aturan main yang telah di sepakati bersama. Walaupun GATT belum lengkap dan sempurna tetapi cakupannya bersifat komprehensif. Sebagai suatu perjanjian yang dicapai melalui suatu negosiasi maka perjanjian GATT mengandung banyak kompromi yang mencerminkan keperntingan yang berbeda diantara Negara peserta perundingan. Karena itu, maka sebagai suatu perjanjian yang diwujudkan melalui negosiasi dan kompromi, perjanjian GATT merupakan hal yang kompleks. ${ }^{3}$

Disepakatinya GATT didasarkan pada hubungan antar negara di bidang perdagangan dan ekonomi harus dijalankan dengan sasaran untuk meningkatkan standar hidup, menjamin lapangan kerja dan meningkatkan penghasilan dan penemuhan kebutuhan, pemanfaatan sumber daya dunia seutuhnya serta memperluas produksi serta pertukaran barang. Cara untuk mencapai tujuan-tujuan ini adalah dengan mengadakan pengaturan timbal balik dan saling menguntungkan untuk mengurangi tariff dan hambatan perdagangan lain, serta menghilangkan diskriminasi dalam perdagangan internasional. Dalam tahun-tahun berikutnya berbagai tambahan dan penyempurnaan telah dilakukan melalui berbagai perundingan (round). Delapan putaran perundingan yang telah diselesaikan yakni Jenewa (1947), Annecy (1949), Torquay (1950-1951), Jenewa (1953-1956), The Dilon Round (1960-1961), The Kennedy Round (1964-1967), Tokyo Round (1973-1979) dan terakhir Uruguay Round (1986-1994).

\footnotetext{
${ }^{1}$ H.S Kartadjoemena, Substansi Perjanjian GATT/WTO dan Mekanisme Penyelesaian Sengketa, UI Press, Jakarta, 2007, Hal 3

2 H.S Kartadjeomena, GATT dan WTO : Sistem, Forum dan Lembaga Internasional di Bidang Perdagangan, UI Press, Jakarta,2002

${ }^{3}$ H.S Kartadjoemena, Substansi Perjanjian GATT/WTO dan Mekanisme Penyelesaian Sengketa, Op.Cit, Hal.4
} 
Dalam GATT, perselisihan di antara pihak-pihak yang bersangkutan atau dengan perantara CONTRACTING PARTIES (organ utama GATT yag terdiri dari Negara-negara anggota yang bertindak bersama-sama). Jika perselisihan tidak dapat diselesaikan maka akan diserahkan kepada CONTRACTING PARTIES sendiri yang kemudian akan melakukan penyelidikan, dan memberikan rekemondasi atau putusan bagi pihak-pihak yang bersangkutan. Dalam pratek CONTRACTING PARTIES dalam memutuskan perselisihan tersebut dibantu oleh sebuah panel yang terdiri dari para ahli. Atas dasar temuan panel inilah CONTRACTING PARTIES memberikan rekemendasi atau putusan. ${ }^{4}$

Perbaikan mekanisme penyelesaian sengketa merupakan salah satu aspek pembaharuan norma-norma GATT yakni aspek procedural. Aspek substantive yang erat kaitannya dengan aspek procedural, sehingga perbaikan aspek yang satu harus diimbangi dengan perbaikan aspek yang lainnya. Perbaikan aspek procedural harus tidak akan membangkitkan kepatuhan Negara anggota untuk menggunakan sarana penyelesaian sengketa GATT apabila dirasakan bahwa aturan-aturan substantifnya sudah tidak dapat diterima lagi. Demikian pula perbaikan aspek substantive tidak dengan sendirinya akan menjamin kepatuhan, apabila tidak ada mekanisme penyelesaian sengketa yang baik dan efektif.

Sistem penyelesaian sengketa yang telah melembaga dan mengandung prosedur yang telah rinci menjadi bagian integral dari suatu lembaga internasional yang bertanggungjawab "mengadministrasikan" perjanjian tersebut dan menjadi forum untuk pelaksanaan dan pengelolaan perjanjian itu. Penguasaan yang lengkap dari GATT dan WTO memerlukan pula penguasaan tentang prosedur penyelesain sengketa. Namun untuk menguasai system penyelesaian sengketa GATT dan WTO secara lengkap memerlukan pula penguasaan aturan main yang berlaku dan identifikasi dari aspek aturan main tersebut yang mungkin dapat menjadi sumber sengketa.

\footnotetext{
${ }^{4}$ Hata, Perdagangan Internasional Dalam Sistem GATT dan WTO : Aspek Hukum dan Non Hukum, Refika Aditama, Bandung, 2006, hal 2-3
} 
Berdasarkan latar belakang diatas penulis tertarik untuk melakukan penelitian dengan judul " Mekanisme Penyelesaian Sengketa GATT dan WTO Ditinjau Dari Hukum Penyelesaian Sengeta Internasional".

\section{Metode Penelitian}

Metode penelitian yang digunakan yakni penelitian hukum normative. Penelitian hukum normative ialah penelitian yang mengkaji studi dokumen yakni menggunakan berbagai data sekunder seperti peraturan perundang-undangan, teori hukum dan pendapat para sarjana. Sedangkan teknik pengumpulan data yang digunakan ialah studi kepustakaan.

\section{Hasil Penelitian dan Pembahasan}

\subsection{Mekanisme Penyelesaian Sengketa Sebagai Bagian dari Pengawasan Internasional}

Salah satu fungsi penyelesaian sengketa adalah agar supaya norma-norma hukum yang mengatur hubungan diantara anggota masyarakat dipatuhi. Dengan kata lain didalam nya terdapat fungsi pengawasan. Dalam masyarakat nasional, pengawasan ini dipercayakan pada suatu lembaga yaitu negara, sedangkan dalam masyarakat internasional yang tidak mempunyai kekuasaan sentral diserahkan pada para anggotanya sendiri.

Menurut Van Hoof ${ }^{5}$ pengawasan internasional mempunyai tiga fungsi :

1) Review Function : Pada umumnya "review" duartikan sebagai mengukur atau menilai sesuatu berdasarkan tolak ukur tertentu. Dalam konteks hukum, ini berarti

\footnotetext{
${ }^{5}$ Kaasik, sebagaimana yang dikutip GJH Van Hoof \& K.de vey Mestdagh, Mechanism of Internasional Supervision, Bahan Penataran Hukum Ekonomi UNPAD
} 
menilai sesuatu perilaku untuk menentukan kesesuainnya dengan aturan hukum. Pengawasan ini dilakukan oleh satu negara atau lebih atau oleh suatu lembaga yang dibentuk menurut perjanjian internasioal. Hasil dari pengawasan ini adalah suatu keputusan tentang sesuai tidaknya negara tersebut dengan hukum internasional.

2) Correction Function : Fungsi ini dilaksanakan manakala telah timbul suatu keadaan yang bertentangan dengan hukum internasional. Namun demikian, fungsi ini dapat pula bersifat preventif, manakala negara-negara menyesuaikan diri pada aturan hukum internasional sebagai akibat eksistensi atau ancaman dari mekanisme koreksi ini.

3) Creative Function : sekali pun review dan creative function merupakan bagian pokok dari pengawasan, namun pengawasan juga dapat berfungsi kreatif, terutama dalam hukum internasional. Hal ini disebabkan karena tidak adanya lembaga eksekutif dan judikatif. Jadi fungsi kreatif ini berupa penafsiran atas aturan-aturan hukum internasional yang belum jelas.

Dalam keranga teoritis tersebut diatas maka mekanisme penyelesaian sengeta internasional merupakan salah satu bentuk dari mekanisme pengawasan dalam hukum internasional. Sejauh mana GATT dan WTO memberikan pengaturan tentang pengawasan ini. Dalam kedua sistem tersebut pengawasan dilaksanakan oleh berbagai badan yang terdapat di dalamnya. Dalam GATT oleh CONTRACTING PARTIES, Council, Panel, Working Party. Dalam WTO terdapat Ministerial Conference, General Council yang antara lain melaksanakan tugas sebagai Dispute Settlement Body. Disamping itu WTO dilengkapi dengan berbagai dewan (Council) lain yang melakukan pengawasan di bidang masing-masing sesuai dengan covered agreement WTO seperti Council Trade in Goods, Council For Trade and Service. ${ }^{6}$

\footnotetext{
${ }^{6}$ Hata, Op.Cit, hal 182
} 
Secara normatif GATT dan WTO menyediakan sejumlah ketentuan pengawasan di dalamnya. Misalnya, dalam GATT Pasal $X$ mengandung ketentuan tentang pengawasan secara umum. Pasal ini mewajibkan negara-negara menerbitkan aturanaturan nasinal yang terkait dengan perdagangan internasional. Ini merupakan review function dari pengawasan. Ketentuan pengawasan secara khusus dapat ditemukan dalam Pasal XI dan XIII yang mengatur pengawasan di bidang moneter kepada IMF.

Dalam sistem WTO ketentuan-ketentuan tadi disempurnakan dan diperluas cakupannya sesuai dengan pengaturan bidang-bidang yang semula tidak terdapat dalam GATT 1947. Pasal XXII dan XXIII, misalnya dilengkapi dengan Understanding on Rules and Procedures Governing the Settlement of Dispute. Pasal III dari General Agreement on Trade in Services, misalnya mengandung ketentuan tentang keharusan menerbitkan peraturan nasional terkait dengan materi yang terdapat dalam perjanjian internasional ini demi transparansi. Pasal VI mengharuskan penagangan yang objektif dan tidak memihak dalam kaitannya dengan peraturan nasional yang terkait dengan specific commitment yang telah dibuat. Ketentuan pengawasan ini dipertegas lagi dalam annex yang menyangkut pengaturan di bidang jasa tertentu.

\subsection{Hubungan Metode Penyelesaian Sengketa GATT dan WTO dengan Penyelesaian Sengketa Internasional}

Dalam konteks masyarakat internasional secara umumnya, masyarakat internasional memberikan peluang untuk melakukan penyelesaian sengketa antar negara melalui berbagai cara. Sengketa antar negara dapat diatasi melalui proses politisdiplomatik yakni secara non-yudisial atau sebagai alternatif, dapat pula dilaksanakan dalam forum tribunal (hukum). Rincian dari kedua kategori forum dan variasi dari ciri dalam metode penyelesaian sengketa tersebut dapat dilihat dalam uraian dibawah ini : 


\section{A. Jalur Non-Yudisial}

Peyelesaian sengketa melalui jalur non-yudisial adalah penyelesaian yang dilakukan melalui proses politis-diplomatis. dalam bentuk yang lebih fleksibel, serta dengan ketentuan prosedural yang lebih luwes, penyelesaian sengketa dapat diselesaikan oleh pihak yang bersengketa sendiri tanpa keterlibatan pihak lain yakni melalui proses negosiasi. Dengan proses maka sengketa diselesaikan melalaui pendekatan non-yudisial yang berdasarkan atas pertimbangan politis antara pihak yang bersengeketa dengan menggunakan mekanisme diplomatik. Cara penyelesaian sengketa yang diselesaikan antara pihak yang bersengketa sendiri, walaupun dubantu dengan pihak ketiga yang dapat berupa good offices, mediasi atau konsiliasi.

\section{1) Negosiasi dan Konsultasi}

Proses negosiasi dengan bentuk yang luwes tersebut memang merupakan salah satu aspek dari kegiatan sistem GATT dan WTO yang terpenting. Dalam kenyataan sebenarnya, sebagai sistem GATT dan WTO merupakan forum negosiasi yang berfungsi setiap waktu. Dalam prosedur GATT ada mekanisme konsultasi yang merupakan aspek khusus dari mekanisme negosiasi. Dalam sistem GATT, konsultasi dalam rangka proses penyelesaian sengketa mengandung arti formal karena secara eksplisit terdapat dalam Pasal XXII perjanjian GATT walaupun dalam pelaksanaannya proses konsultasi bentuknya dapat berupa proses yang sangat informal dan tidak terlihat oleh pihak lain.

\section{2) Good Offices}

Good Offices merupakan cara penyelesaian sengketa dalam bentuk yang non-yudisial dengan bantuan pihak ketiga yang dianggap netral. Pihak ketiga yang melakukan kegiatan good offices bertindak sebagai pihak yang mendorong agar 
pihak yang bersengketa mengambil langkah konkret kearah penyelesaian secara damai tetapi tidak turut dalam proses perundingan.

\section{3) Mediasi}

Dalam proses penyelesaian sengketa melalui mediasi pihak ketiga juga turut dalam proses perundingan untuk penyelesaian sengketa tetapi pengambilan keputusan tentang penyelesaian sengketa berada dalam pihak yang bersengeta.

\section{4) Konsiliasi}

Dalam hal konsiliasi, pihak ketiga merupakan pihak yang diminta menjadi a commision of persons yang tugasnya adalah untuk menjelaskan fakta yang berkaitan dengan sengketa dan menyusun laporan yang isinya mencakup usulan mengenai penyelesaian yang dianggap dapat diterima walaupun usulan tersebut tidak mengikat.

\section{B. Jalur Yudisial}

Penyelesaian sengketa dalam bentuk yang jauh lebih formal dan yang secara langsung aktif melibatkan pihak ketiga dapat berupa arbitrase atau berupa juducial settlement. Dengan menggunakan jalur ini maka hasil dari proses penyelesaian sengketa yang ditempuh ditetapkan oleh pihak ketiga dan berlaku secara mengikat. Dengan demikian maka jalur ini merupakan jalur yuridis. Penyelesaian sengketa yang dpilih melalui jalur arbitrase maupun jalur judicial settlement merupakan jalur yudisial yang sifatnya suatu tribunal.

\section{Kesimpulan}

Mekanisme penyelesaian sengketa GATT dan WTO ditinjau dari hukum ekonomi internasional dapat dilakukan melalui 2 cara yakni non-yudisial dan yudisial. Non-yudisial 
meliputi negosiasi, mediasi, good efficer, konsiliasi sedangkan yudisial dapat dilaksanakan melalui arbitrase atau judicial settlement.

\section{DAFTAR PUSTAKA}

Hata, Perdagangan Internasional Dalam Sistem GATT dan WTO : Aspek Hukum dan Non Hukum, Refika Aditama, Bandung, 2006

Kartadjoemen HS, Substansi Perjanjian GATT/WTO dan Mekanisme Penyelesaian Sengketa, UI Press, Jakarta, 2007

Kartadjeomena HS, GATT dan WTO : Sistem, Forum dan Lembaga Internasional di Bidang Perdagangan, UI Press, Jakarta

Kaasik, sebagaimana yang dikutip GJH Van Hoof \& K.de vey Mestdagh, Mechanism of Internasional Supervision, Bahan Penataran Hukum Ekonomi UNPAD 